“Zoologischer Anzeiger," Jahrg. VII., No. 184 : Jahrg. VIII., No. 185, 29th December, 1884, and 12th January, 1885. From the Editor.

"Abstract of Proceedings of the Royal Society of Tasmania," January 26th, 1885. From the Society.

"Proceedings of the Academy of Natural Sciences of Philadelphia," Part II., May to October, 1884. From the Editor.

"Mittheilungen aus der Zoologischen Station zu Neapel." Fünfter Band, III. and IV. Heft. From the Director.

"Monatliche Mittheilungen des Naturwissenschaftlichen Vereins des Regierungsbezirkes Frankfurt." Jahrg. II., Nos. 8 and 9. November and December, 1884. From the Society.

PAPARS READ.

\title{
ON SOME REPTILIA LATELY RECEIVED FROM THE HERBERT RIVER DISTRICT, QUEENSLAND.
}

By William Macleay, F.L.S., \&c.

I have frequently, within the last two years, received from my friend, Mr. J. A. Boyd, of Ripple Creek, Ingham, collections of Mammals, Reptiles, and Fishes made in the vicinity of the Herbert River ; and I have, I believe, more than once, expressed my surprise at the wonderful richness of the Fauna of that district of Northern Queensland. I have now to record the receipt from the same district and the same gentleman, of two drums of spirit specimens, the contents of which fully bear out the reputation of the district for the abundance of its animal life. The Mammals and Fishes of the collection I shall probably have some. thing to say about on another occasion. I shall at present confine myself to some notices of the Lizards and Snakes, with which the district seems to abound. 
Class. REPTILIA.

Order. SAURIA.

Family. Scincide.

\section{Hinulia picta. n. sp.}

Rostral shield large, very obtusely angled at its contact with the præfrontal. Nasal shields small, distant. Præfrontal large, rounded in front, and truncate behind with the exception of a small lobe in the middle. Postfrontals pentagonal, in contact with the præfrontal on their anterior face, and with the vertical behind. The vertical is four-sided, the anterior faces forming a short triangle, the posterior a long one. At the base and on each side of the apex of the vertical, are two rather small occipital shields, and behind these three larger ones, the middle of these being narrower than the others. The orifice of the ear is round and smooth The general colour is a pale lavender grey, slightly darker on the back and tail than on the belly; the scales are uniformly smooth and glossy. On the head and neck are numerous black and brown marks which appear to take the following order : -An ill-defined black band encircles the nose and muzzle; another, broad and composed of two black streaks with the intervening space brownish, extends from beneath the eye across the throat, where it is connected with the first band ; the third of the same double character, extends from the ear across the throat; immediately behind this a very broad band extends across the nape, the hinder portion of it forming a distinct double black band extending to the fore legs. Behind this the body is marked by 12 equidistant, narrow, undulating, parallel, black, more or less white edged, bands not extending on the belly. The tail is similarly marked, but the bands are straight.

One specimen. Length, 8 inches.

This is a very beautitul species. The disposition of the head shields differs considerably from that of most if not all the species of this very numerous Australian genus, excepting perhaps Hinulia Gerrardi 


\section{Tetradactylus guttulatus. n. sp.}

Entirely of a nitid bronzy brown paler on the belly, every scale with one or more very minute black spots, a few palish marks on and about the labial shield. The nasal shields are widely separated by the frontal, behind the frontal lies the vertical, which is in form of a triangle with rounded apex, behind it there are two pentagonal occipital shields and behind these are three others larger, the middle one triangular and enclosed between the two lateral shields. There is a deep longitudinal impression from the mouth to the eye along the summit of the first three labial shields. The ear orifice is round and open. The legs are weak and distant as in the genus, and the tail is very elongate. Length, 6 inches.

One specimen only.

\section{Order. OPHIDIA.}

Family. BoIdæ.

$$
\text { Nardoa crassa. n. sp. }
$$

\begin{tabular}{|c|c|}
\hline Scales in..... & 42 rows \\
\hline Abdominal Plates ................ & 280 \\
\hline Anal Plate....................... & undivided \\
\hline Sub-caudal Plates ................ & $52 / 52$ \\
\hline Total length .......... & 68 inches \\
\hline Tail $\quad . . . . . . .$. & 7 inches \\
\hline Head ............................ & 2 inches \\
\hline Girth of body $\quad \ldots \ldots \ldots \ldots \ldots . . . .$. & 7 inches. \\
\hline
\end{tabular}

The body of this snake is thick and cylindrical, the tail short, chick and tapering to a blunt point; the head is narrow and elongate for the family. The rostral shield is broad and low ; the anterior frontals are oblong; the posterior frontals are very long, (in Nardoa Gilberti there are two pair), the vertical is nearly as broad as long and polygonal ; the first upper labial shield, and the four posterior lower labials are pitted. The eye is rather small and comes in contact with the sixth and severith upper labial shields.

The upper surface of the head and body and the tail is of a brownish black, the side scales becoming paler towards the belly, 
which is yellowish white. The abdominal plates are little more than twice the widths of the body scales nearest them, which grow rapidly narrower towards the back. The labial shields are yellowish.

I received from $\mathrm{Mr}$. Boyd three specimens of this powerful snake, and the above description is taken from the largest of the three.

The genus Nardoa was originally created by Gray in 1842, for the reception of two Snakes, one which he named Gilberti, from Port Essington, the other Schlegelii, from New Ireland. The first of these has since been got from Port Denison and Port Darwin, but I am not aware that the New Ireland species has ever been taken again.

The present is a very distinct well marked species. The genus will very probably be found in New Guinea.

\section{Tropidonotus àter. n. sp.}

$\begin{array}{ll}\text { Scales in....................... } & 14 \text { rows } \\ \text { Abdominal Plates } \ldots \ldots \ldots \ldots \ldots \ldots & 147 \\ \text { Anal Plate } \ldots \ldots \ldots \ldots \ldots \ldots \ldots \ldots . & \text { bifid } \\ \text { Sub-caudal Plates } \ldots \ldots \ldots \ldots \ldots \ldots & 64 / 64 \\ \text { Total length } \ldots \ldots \ldots \ldots \ldots \ldots \ldots \ldots & 30 \text { inches } \\ \text { Tail } \ldots \ldots \ldots \ldots \ldots \ldots \ldots \ldots \ldots \ldots \ldots & 5 \frac{1}{2} \text { inches }\end{array}$

This a handsome active looking Snake. The head and headshields exactly correspond with those of $T$. picturatus, but the body is of slighter make, and the tail is very fine and tapering. The colour is jet black on the entire upper surface; the abdominal and sub-caudal plates are of a pinkish-white with a dark band on the base of each plate, giving much the appearance of the marking on the belly of the Black Snake-Pseudechis porphyriacus. Three species of Tropidonotus are now known to inhabit Australia, two of these $T$. angusticeps and the present species $T$. ater have been described by me from specimens taken at the Herbert River, and the third species $T$. picturatus $I$ have also seen from that district. 


\section{Hoplocephalus assimilis. n. sp.}

Some months ago I received from Mr. Boyd a species of Hoplocephalus which, with some hesitation, I referred to the Sydney species Hoplocephalus nigrescens, Gunth. I received from Mr. Boyd on this last occasion, two other specimens of the same snake, and I am thereby enabled to pronounce positively that the Sydney and Herbert River specimens belong to different species. I propose the name given above for the Herbert River species.

Scales in.................... 15 rows

Abdominal Plates ............. 192

Anal Plate .................. single

Sub-caudal Plates ............. 37

Total length ................. 17 inches

Tail.......................... $2 \frac{1}{2}$ incbes.

The head shields are almost identical with those of $H$. nigrescens, excepting that the anterior frontals are shorter, being less than half the length of the posterior, and the loreal space is taken up by the nasal and anterior oscular shields, completely separating the second labial and posterior frontal. The superciliaries are only half the length of the vertical, which is broad, six sided, and triangular behind. The eyes are very small, and the post-orbitals vary in number from 1 to 3 . The tongue is not white as in $H$. nigrescens. The colour is black above, beneath it varies from a pinkish colour in some specimens, to an almost leaden gray colour in others. 


\section{$2 \mathrm{BHL}$ Biodiversity Heritage Library}

Macleay, W. 1885. "On some Reptilia lately received from the Herbert River district, Queensland." Proceedings of the Linnean Society of New South Wales 10, 64-68. https://doi.org/10.5962/bhl.part.17898.

View This Item Online: https://www.biodiversitylibrary.org/item/30482

DOI: https://doi.org/10.5962/bhl.part.17898

Permalink: https://www.biodiversitylibrary.org/partpdf/17898

\section{Holding Institution}

MBLWHOI Library

\section{Sponsored by}

MBLWHOI Library

\section{Copyright \& Reuse}

Copyright Status: NOT_IN_COPYRIGHT

This document was created from content at the Biodiversity Heritage Library, the world's largest open access digital library for biodiversity literature and archives. Visit BHL at https://www.biodiversitylibrary.org. 